\title{
Trial of New Education Programs Effectively Utilizing Teaching Opportunities
}

\author{
Makoto Hasegawa Member (Chitose Institute of Science \& Technology) \\ Koji Ishida Non-member (Chitose Institute of Science \& Technology)
}

Keywords : science experiments, class programs, teaching material development, presentation, general study class

\section{Introduction}

In recent years, students in elementary schools through senior high schools seem to be less interested in science and technology as well as manufactuaring. Moreover, in universities, achieved levels of knowledge and capabilities of students are said to be declining. In order to overcome those problems, some kinds of new education schemes have to be introduced.

For the purpose of stimulating mainly elementary and/or junior high school students to be interested in the fields of science and technology, science experiment schools and/or classes are widely held. At such experiment schools held at our university, undergraduates often take part therein as assistants. After the experiment schools, those undergraduates tend to say that they got important experiences through explanation to childrens, in which they can realize some areas and/or points in their knowledge are required to be re-studied or re-organized. This indicates that teaching and explaining some knowledge to the others can be important and useful opportunities in education.

Accordingly, new education programs for undergraduates and/or high school students have been tried in which teaching opportunities are effectively utilized.

\section{Relay-teaching from Undergraduates to High School Students and Further to Elementary School Students}

First, a new style of education, "relay-teaching" from undergraduates to high school students further to elementary school students, was tried in the Science Experiments School.

More specifically, in the experiments school held for the purpose to stimulate elementary school students to be interested in the fields of science and technology, undergraduates first explained the contents and procedures of experiments to high school students. Thereafter, these high school students in turn acted as tutors who explained the contents and procedures of experiments to elementary school students. Although most of the high school students had not learned physics thoroughly, they tried their best in making elementary school students well understand. In addition, the undergraduates tended to realize it difficult to make effective presentation for audience who might be unfamiliar with topics (in this case, high school students not having enough knowledge of physics.)

By thus providing undergraduates and high school students with opportunities to teach and explain some knowledge to the others, it became possible to allow them to re-recognize and re-construct their own knowledge and improve their presentation-related skills. Accordingly, this style of teaching was found to be an effective education program.

\section{Undergraduates Projects for Developing Science} Experiment Class Programs

Based on the results of the above-mentioned program, a project for undergraduates has been in progress in which they develop science experiment programs to be used in elementary schools. In this project, groups of undergraduates develop teaching programs of science experiment classes and actually demonstrate them in general study classes of elementary schools. Through the development process, the undergraduates can obtain various skills and abilities such as planning and realizing plans, analyzing the results and making required revisions on their own. Moreover, they are also required to make effective presentation (i.e., teaching elementary school students so that they can well understand the contents of classes). This means the undergraduates can get opportunities to improve their presentation-related skills, including preparation of effective presentation materials.

The four programs for elementary schools were already developed and actually demonstrated by the undergraduates in general study classes of some elementary schools, which were successful in attracting interests of children. Moreover, the project was found to be effective in education for the undergraduates in which they can get opportunities to improve their various skills through experiences of teaching and preparation thereof.

\section{Summary}

New education programs are briefly explained in which science experiment schools (classes), intended to stimulate elementary school students to be interested in science and technology, can be effectively utilized for education of undergraduates and/or high school students by providing them with opportunities to teach and explain some knowledge to the others, as well as to develop and prepare teaching programs. Close cooperation among education facilities from elementary schools to universities can provide new schemes for education of science and technology. 


\title{
教える機会を活用した新しい教育プログラムの試み \\ 正員 長谷川 誠* 非会員 石田 宏司*

\author{
Trial of New Education Programs Effectively Utilizing Teaching Opportunities
} \\ Makoto Hasegawa*, Member, Koji Ishida*, Non-member
}

\begin{abstract}
New education programs for undergraduates and/or high school students have been tried in which teaching opportunities are effectively utilized.

First, a new style of education, "relay-teaching" from undergraduates to high school students further to elementary school students, was tried in the Science Experiments School. By providing the undergraduates and high school students with opportunities to teach and explain some knowledge to the others, it became possible to allow them to re-recognize and re-construct their own knowledge and improve their presentation-related skills. Thus, this style of teaching was found to be an effective education program.

Based on results of the above-mentioned program, a project for undergraduates has been in progress in which they develop science experiment programs to be used in elementary schools. The four programs for elementary schools were already developed and actually demonstrated by the undergraduates in general study classes of some elementary schools, which were successful in attracting interests of children. Moreover, the project was found to be effective in education for the undergraduates in which they can get opportunities to improve their various skills through experiences of teaching and preparation thereof.
\end{abstract}

This paper describes the above two new education programs and analyzes educational effects thereof.

キーワード : 理科実験，授業プログラム，教材開発，プレゼンテーション，総合的な学習の時間

Keywords : science experiments, class programs, teaching material development, presentation, general study class

\section{1. まえがき}

近年, 初等・中等教育段階における小中学生の理科離れ, 科学技術・ものつくりに対する興味・関心の低下が問題視 される一方で, 大学生の基礎学力の低下が指摘されている。 これらの問題点の原因が教科学習の時間及び内容の減少に あるとして,「総合的な学習の時間」の見直しを求める声も 多方面から出てきている。個々の現象や議論の是非はとも かく, 新しい観点からの教育手法を導入する必要性が高ま っていることは間違いない。例えば，理数系大学のリメデ ィアル教育における $\mathrm{e}$-Learning の活用(1), 専門科目で積 極的に「書く機会」を導入した例(2)などが報告されている。

一方, 理科離れの抑制努力の一環として, 小中学生に理 科や科学技術への関心を持たせる機会を提供する目的で理 科実験イベントが各地で開催されている(3)。本学でも, 地元 の小中学校の総合的な学習の時間などを利用した理科実験 教室を継続的に実施している。

\footnotetext{
* 千歳科学技術大学

干066-8655 千歳市美々 758-65

Chitose Institute of Science \& Technology,

758-65, Bibi, Chitose 066-8655
}

上記のような理科実験教室では，本学学生が TA（ティー チングアシスタント) として参加し, 大学教員の補助にあ たる。その本来の目的は実験教室を円滑に実施することに あるが, 講座実施後に参加学生に感想を聞くと, 大半の学 生から「子どもたちに教えることで自分の理解の度合いが 把握でき，貴重な経験になった」という主旨の反応が得ら れる。これは，「他人に教える機会・経験」が自らの知識の 再認識・再構築に有効であることを意味している(4)。

そこでこのほど，上記のような「他人に教える機会・経 験」を積極的に活用した教育プログラムの試行に着手した。

具体的には，まず，地元向けの理科実験教室において， 従来は TA としての参加であった本学大学生ならびに受講 者として参加する高校生に, より積極的な役割を担っても らう実施形態として,「大学生から高校生へ,さらに小学生 へのリレーティーチング」を試みた(5)。これは, 理科実験教 室の中で, 前述の他人に教える機会を高校生や大学生に積 極的に与えるものであり, 実施後のアンケート結果などか らは，新しい教育機会を提供できたことが確認できた。

さらに, 上記の実績に基づいて, 学生のより主体的な活 動を通じて更なる教育効果・学生のキャリアアップを図る 
とともに, 地域の初等中等教育への貢献を目指して, 学生 グループが主体となった小学生向け理科実験授業プログラ ム開発プロジェクトに着手した ${ }^{(6)}$ 。具体的には, 複数の学生 グループが 1〜2 ケ月かけて 50 分程度の理科実験授業プロ グラムを考案し, 総合的な学習の時間などで実際に演示す る。この過程では, テーマの選定から必要な実験器具の設 計・製作，スライドやテキスト（ワークシート）の作成, さらに実際の演示に至るまでの一連のプロセスを通じて, 学生たちは様々なスキルを獲得・向上させている。

以下，これらの概要や成果・教育効果などをご報告する。

\section{2. リレーティーチングによる実験教室の実施と その教育効果の検討}

〈2·1〉 実験教室の概要リレーティーチングを試み た実験教室は, 平成 16 年度文部科学省・大学等開放推進事 業「大学 Jr.サイエンス事業」に「光のふしぎにふれてみよ う」というテーマで申請し, 採択されたものである(5)。3 日 間に渡って実施し, 小学生 30 名, 高校生延べ 30 名（第 1 日 14 名, 第 2 日 16 名), 大学生 12 名が参加した。

このうち小学生及び高校生について, 学年の内訳は以下 の通りであった。

小学生 : 小 624 名, 小 56 名

高校生: 高 318 名, 高 28 名 高 14 名

高校生は, 道立普通高校 4 校の生徒であったが, 理系／ 文系コースの別などについての情報は収集していない。

一方, 大学生については, 本学の「理科研究サークル」 所属学生並びに過去の理科実験教室での TA 経験者を中心 に募ったが，他の学事日程との関係などで，結果的には， 所属学科及び学年の内訳は以下のようになった。

$\begin{array}{ll}4 \text { 年生（光応用システム学科） } & 8 \text { 名 } \\ 2 \text { 年生（） } & 2 \text { 名 } \\ 2 \text { 年生（物質光科学科） } & 1 \text { 名 } \\ 1 \text { 年生（学科分けは } 2 \text { 年進級時から） } & 1 \text { 名 }\end{array}$

〈2·2〉 リレーティーチングの概要』この実験教室の 本来の目的は小学生に理科・科学への興味・関心の喚起を 目的とすることにあったが，より広い範囲での教育的効果 の達成を目指す目的で, 前述の「大学生から高校生へ, さ らに小学生へのリレーティーチング」という形態を取り入 れた。具体的には，3 日間の日程のうち第 1 日及び第 2 日に おいて，午前中にまず大学生が高校生の参加者に当日の実 験内容を説明・指導し, 続いて午後は, 今度は高校生に小 学生の参加者に対するチューター役として, 実験の指導を してもらった。

このリレーティーチングという指導形態の狙いとして は，以下の点が挙げられる。

大学生に対して,

(1) 他人に「教える」ことを通じて自らの知識を再確 認させる。

(2) 教えるためのプレゼンテーション能力の確認・獲 得・スキルアップを図らせる。
高校生に対して,

(1) 学んだ知識を直ちに活用することによる学習意欲 の刺激を与える。

(2) 他人に「教える」ことを経験させる。

大学生に関しては, 単なる補助ではなく, より主体的な 指導者の役割を任せることで, 既習の知識・能力の再確認 ・ 再認識を図らせることができる。また,「他人に理解しても らうように教える」という機会を通じて, 効果的なプレゼ ンテーションに必要なスキルを認識させる契機にもなる。

一方, 高校生については, 単なる一受講者として受身的 に参加するのではなく, 自らの知識を活用する機会を与え ることで, やはり知識の再確認・再認識を図らせることが できる。特に, 既に持っている知識だけではなく, 本講座 で習得したばかりの知識を直ちに活用するという刺激を与 えることは, 従来の学習機会では得られない経験となる。

小学生の参加者に関しては，これまでの実験教室と同様 に理科・科学への興味・関心を持つ機会を提供するねらい があるが，年齢的に近い高校生がチューター役となること で，質問などをしやすい雾囲気を実現し易い。このように 大学生から小学生に至る世代間の交流を図ることも, 今回 のリレーティーチングのねらいに含まれる。

但し, 今回は中学生を対象としなかった。これは, 中高 生間では年齢的に近すぎて, 効果的な指導が実現できない 可能性に配慮したためである。

なお，各回のサブテーマ及び具体的な実験項目は，以下 の通りである(5)(7),(8)。

第 1 日「光と色のふしぎ」

1. 透過型回折格子フィルムによる分光

2. 各色の光の波長の計算

3. CD, DVD による分光

4. CD, DVDのトラック間隔の算出

5. 光の三原色と色の三原色 ( $\rightarrow$ 実際は第 3 日へ)

6. CD $/ \mathrm{DVD}$ 片を用いた簡易分光器の作成

第 2 日「光で音を飛ばしてみよう」

1 . 系電話

2 . 光電話

3. 発光ダイオードを使った光通信

4. 光ファイバを使った光通信

第 3 日「液晶で光のスイッチをつくる」

1 . 液晶セルの作成

2. 作ったセルの動作の確認

3. 光の三原色と色の三原色 (〔第 1 日から)

第 1 日は, 主として光に関する現象のサイエンス的側面 を学ぶことを目的とした。第 2 日は, LED や光ファイバな どを用いた光通信に関する簡単な実験を通じて, 日常生活 で活用されている光テクノロジの一例を体験することをね らいとした。第 3 日は, 簡単な構造の液晶セルを作成して 動作させ, その仕組みを学んでもらった。また, 光の三原 色と色の三原色に関する実験を通じて, ディスプレイやテ レビにおけるカラー表示の原理を学んでもらった。 
上記日程のうち第 3 日は, 高校の学事日程の関係から小 学生のみの参加であった。そのため, 前述のようにリレー ティーチングは第 1 日及び第 2 日に実施した。

実験教室の実施に当たっては，小学生 30 名を 5 つの班に 分け, 各班に $2 \sim 3$ 名ずつの大学生を配置した。これらの班 構成は，3 日間を通じて固定とした。さらに，高校生は，リ レーティーチングを実施した 2 日間について, 同じ高校の 3 〜4名ずつを各班に配置した。但し，2つの班を担当した高 校生は 2 日間を通して参加できたが，残る 3 班を担当した 高校生は 1 日ずつの参加であった。

〈2·3〉 実際のリレーティーチングの状況＼cjkstart実験教室 の第 1 日は, リレーティーチングの初日ということもあり, 午前中の高校生への説明に当たっては，まず大学教員が概 要を説明した。その後に, 大学生から実験内容の細部に関 する指導を行った。

参加した高校生の多くは，高校で物理を履修していない か，あるいは履修中でも今回の実験内容に該当する単元ま で学習が進んでいない状態であった。しかし，それにもか かわらず, 大半の高校生参加者に, 第 1 日の実験内容に関 係する波の性質や回折, 干渉, さらに波長計算の原理まで, よく理解してもらうことができた。その結果として, 高校 生による午後の小学生への説明も比較的円滑に進行した。 また，この小学生に対する説明の中では，難しい用語を使 わずに波の干渉のような現象を説明するかに, 非常に苦労 している様子が見て取れた。

第 2 日は，第 1 日の経験を踏まえて，高校生への概要説 明も大学生の一人に担当してもらい, 大学教員はサポート 役に徹した。この大学生には説明内容の検討・ストーリー 作りまで任せたが，例えば「振動というような難しい表現 は使わずに，平易な言い方に置き換えるように」など，小 学生への指導の仕方に関するアドバイスも含めて, 十分な 内容の説明を行っていた。

なお, 前述のように第 2 日に参加した高校生のうちの約 半数が第 1 日から入れ替わっていたが，小学生に対して全 体的にスムーズな指導を行っていた。

図 1 及び図 2 には, 講座当日の大学生から高校生, 及び 高校生から大学生への指導風景の写真を示す。高校生から 大学生へ, 小学生から高校生や大学生への質問も活発に発 せられていた。これには, 講座参加者間の年齢差が比較的 小さいことによる効果に加えて，4～5 名の小学生からなる 各班に 3〜4名の高校生がつき, さらにほぼ同数の大学生が サポートする体制が，一種のチームティーチング効果を生 み出したことも挙げられる。特に, 第 1 日及び第 2 日の 2 日間を通じて同じ高校生が参加した 2 つの班については, 班を構成するメンバが完全に固定されていたことにより， 特に第 2 日において, より打ち解けた雰囲気での実験指導 が実現できていたようであるが, 他の 3 班との詳細な比較 検討は行っていない。

〈2·4〉 リレーティーチングの教育効果の検討 今回 のリレーティーチングの効果を検討する目的で, 第 1 日及

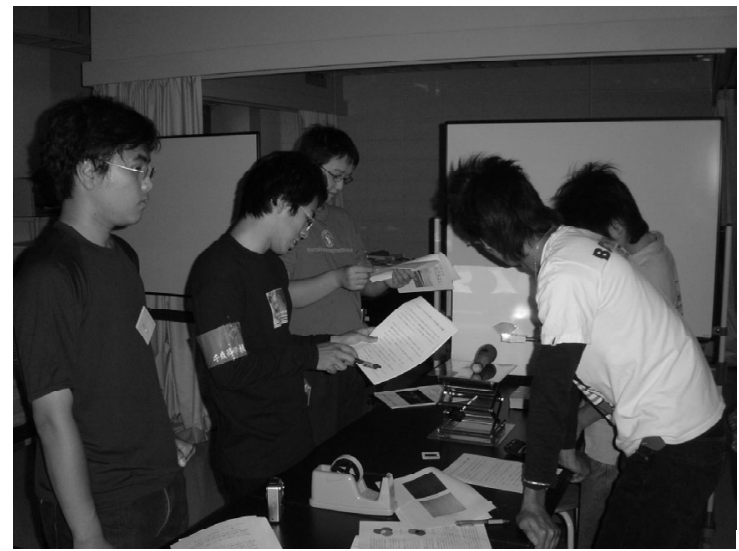

図 1 大学生から高校生一の指導風景

Fig. 1. Explanation by undergraduates to high school students.

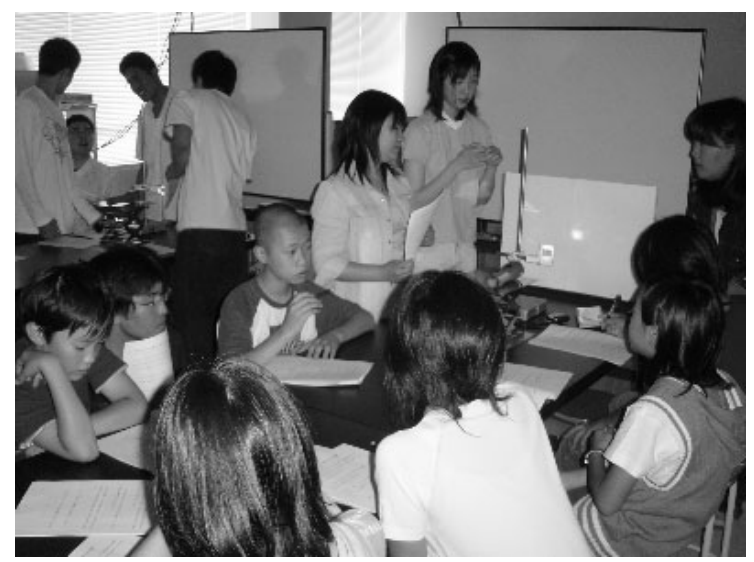

図 2 高校生から小学生への指導風景

Fig. 2. Explanation by high school students to elementary school children.

び第 2 日の参加者（高校生ならびに小学生）に対して, 簡 単なアンケートを行った。ここでは, そのうち以下に示す 3 つの設問に対する回答の集計結果を，表 1 表 3 に示す。

設問 1 (表 1 )

講師の説明や実験の内容は理解しやすかったか?

設問 2（表 2)

実験教室の内容は全体に難しかったか?

設問 3(表 3)

全体としてこの実験教室に十分満足しているか?

設問 1 に関して, 表 1 に示すように高校生の $92 \%$, 小学 生の $79 \%$ が「講師の説明や実験の内容は理解しやすかった と思う」又は「ややそう思う」と回答した。これより，高 校生に対する大学生の説明, 小学生に対する高校生の説明 とも比較的わかりやすい内容が実現できたといえる。

この結果, 表 2 に示す設問 2 の回答結果にあるように, 今回の実験教室の内容を難しいと感じる割合はあまり高く なかった。特に高校生の参加者にとっては, 当日午前中に 学んだ内容を午後に直ちに活用して小学生を指導するとい 
表 1 設問 1 に対する回答

Table 1. Responses to the first questionnaire.

"Were the tutors' explanation and the contents of experiments easy to understand?"

\begin{tabular}{|l|c|c|}
\hline & High school students & Elem. school children \\
\hline Yes & $39 \%$ & $25 \%$ \\
\hline Rather yes & $53 \%$ & $54 \%$ \\
\hline Rather no & $4 \%$ & $14 \%$ \\
\hline No & $4 \%$ & $7 \%$ \\
\hline
\end{tabular}

表 2 設問 2 に対する回答

Table 2. Responses to the second questionnaire.

"Were the contents of experiments difficult as a whole?"

\begin{tabular}{|l|c|c|}
\hline & High school students & Elem. school children \\
\hline Yes & $9 \%$ & $14 \%$ \\
\hline Rather yes & $22 \%$ & $18 \%$ \\
\hline Rather no & $56 \%$ & $50 \%$ \\
\hline No & $13 \%$ & $18 \%$ \\
\hline
\end{tabular}

表 3 設問 3 に対する回答

Table 3. Responses to the third questionnaire.

"Were you well satisfied with this experiment school as a whole?'

\begin{tabular}{|l|c|c|}
\hline & High school students & Elem. school children \\
\hline Yes & $44 \%$ & $42 \%$ \\
\hline Rather yes & $43 \%$ & $29 \%$ \\
\hline Rather no & $4 \%$ & $18 \%$ \\
\hline No & $9 \%$ & $11 \%$ \\
\hline
\end{tabular}

う状況であったにもかかわらず，内容をよく理解して小学 生に分かりやすい説明を行ってもらえたと考えられる。

さらに，今回の実験教室の満足度に関寸る設問 3 につい て，表 3 に示寸ように $80 \%$ を超える高校生参加者から満足 できた旨の回答が得られた。個別の感想としては，「自分で は理解していたつもりでも，実際に説明すると，なかなか 言葉が出てこなかった」「今回の講座で取り扱った物理現 象に興味を持つことが出来た」などの意見が挙げられた。

一方，参加した大学生から，「自分では分かりや寸く高校 生に説明したつもりであったのに，小学生に対寸る彼らの 説明を聞いていると想定したようには理解してもらえてい なかったことがあり，説明の仕方などに関する反省点が多 かった」という感想があった。参加学生の $2 / 3$ は前述のよ うに 4 年生であり, 彼らは既に PowerPoint を用いたプレゼ ンテーションを授業の中などで経験していた。しかし，大 学教員や同じ学生を対象と寸るそれらのプレゼンテーショ ンと, 本講座における高校生相手の説明とでは相違点があ ったようである。前述のような学生の感想は, 今回のリレ ーティーチングが，単なる知識の再認識・再構築に留まら ず，効果的なプレゼンテーションを行うためのスキルの重 要さを自ら認識する契機となり得ることを示している。
このように, リレーティーチングという実験教室の実施 形態は, 高校生や大学生に「教える機会」を積極的に与え ることを通じて, 彼らに対する学習・スキルアップの動機 付けとしての効果があると考えられる。

但しその一方で，小学生の理科離れ抑制への貢献という 実験教室の本来の目的を考えれば，今後の改良・工夫が必 要となる点が認められる。

寸なわち, 表 3 に示寸参加者の満足度の結果のうちで小 学生からの回答結果を見ると,「満足したと思う」又は「や やそう思う」という回答は $71 \%$ に留まっている。この理由 として, 第 1 に, 小学生向けの実験教室としては, 内容 (実 験テーマ）の設定が適切ではなかった可能性が挙げられる。 学校での授業内容に関連させたり, 日常生活の中で体験で きる現象に関連付けたりするなど，より興味を抱かせる工 夫の余地がある。また第 2 に, 今回のリレーティーチング の実施形態に起因する要素が挙げられる。すなわち, 今回 は, 高校生の参加者は事前に実験テーマや内容を知らされ ることなく当日に説明を受け，直ちにそれを小学生に説明 しなければならなかった。このため, 比較的分かりやすい 説明は行えたものの，小学生の興味を駆り立てるほどの踏 み込んだ説明の実現までは難しかったとも考えられる。こ れらの点は，今後の検討事項である。

\section{3. 大学生による小中学生向け理科実験授業開発 プロジェクトとその教育効果の検討}

〈3・1〉 プロジェクトの概要 上述のように，小学生 に対して理科・科学に関する興味・関心を抱いてもらうき っかけ・動機付けを提供することを目的として行う理科害 験教室において，大学生や高校生に「教える機会」を積極 的に与えることで, 彼らに対する教育の場として活用でき ることが確認された。そこで，この結果を踏まえて，地域 教育への協力・貢献活動であるこれらの理科実験教室活動 を本学学生の教育の場としてさらに積極的に活用しようと する取組みを, 平成 16 年度の秋から実施している(6)。これ は, 平成 16 年度の文部科学省「現代的教育ニーズ取組支援 プログラム（現代 GP）」の「地域活性化への貢献」テーマ として採択された事業である。

本プロジェクトは，以下の 3 点を主な目標としている。

（1）地域の小中学校の教諭の協力を得ながら, 学生が主 体となり, 理科実験教材とそれに関連するコンテンツが一 体化した学習教材・システムを制作する。また，それらを 利用した実験授業プログラムを立案し，それに従った実験 授業を学生が実施する。

（2）参加学生は，教材テーマの選定から検討・製作・実 施・改善に至る一連のプロセスを通じて, 問題提起・分析 · 解決型の学習能力を獲得する。

（3）制作された学習教材・システムを電子化して地域全 体で共有化することで，地域の初等中等理科教育の活性 化・理科離れの抑制に貢献する。

学生教育という観点から見ると, 課題の設定（教材テー 
マ選定）から解決（教材完成及び演示）に至る過程で, 企 画力・実行力・プレゼンテーション力など様々な能力・ス キルの向上の機会を学生に提供できる。また, 作成した実 験教材を利用して小学校の総合的な学習の時間などで実際 に学生に実験デモンストレーションを行わせることは, 前 述の「教える機会・経験」を通じた知識の再確認・再構築 の場となる。特に, 最終的に自らが教える場面を想定して 教材や授業プログラムを考案・作成することは, 教員養成 課程に属さない一般の理工系学生にとっては, 本来の授業 カリキュラムでは決して体験できない内容である。

上記プロジェクトの実施にあたって, 趣旨に興味を示し た学生によるグループを組織した（平成 16 年秋の開始時点 では, 2 グループ計 12 名の学生が参加)。また, 活動の場と して, 学内に専用の実験室を確保した。なお, 本プロジェ クトは現時点ではカリキュラム化されておらず, 単位取得 を目的とした活動ではない。

また, 小学校で実際に活用し易い実験教材とするため, 地域小学校の教諭 4 名に地域アドバイザとして参画して頂 き, 内容などに関するアドバイスを得ている。具体的には, 実験授業の開催日程に応じて学生たちが頻繁に小学校に出 向いて, 実験内容の打合せを行っている。

〈3·2〉 プロジェクトの立上げ＼cjkstart平成 16 年秋のプロジ エクト開始時点での参加学生の学年内訳は, 4 年生 2 名, 3 年生 4 名, 2 年生 3 名, 1 年生 3 名であった。このうち 4 年 生 2 名, 2 年生 3 名, 1 年生 1 名は本稿 2 .で述べたリレーテ イーチングの経験者であり, 3 年生 4 名は全員が過去の理科 実験教室における TA 経験者であった。これらの 10 名は小 中学生を対象とした理科実験授業の「経験者」であり, 全 くの初心者は 1 年生 2 名であった。

学生のグループ分けに関して, 3 年生以下の 10 名を 2 グ ループに分け, 3 年生 1 名ずつにグループリーダを任せた。 所属学科及び学年の別は，両グループでほぼ均等にした。 なお, 4 年生 2 名は, 卒業研究のため十分な活動時間の確保 が難しいことから，グループメンバとしてフルに関与する のではなく, 助言・サポートを行う学生アドバイザとした。

グループの活動方法やグループ内での学生の役割分担な どは基本的に教員が関与せず，各リーダを中心とした学生 の主体性に任せた。当初は明確な役割分担もなく集団的に 作業を進めていたが，最終的に実験の期日が迫るにつれて， PowerPoint 等の資料作成, 実験器具の最終準備などを分担 しながらの作業になっていたようである。

平成 16 年秋以降, 上記の 2 つの学生グループがそれぞれ 約 50 分間の実験授業プログラムを立案し, 平成 16 年 12 月 及び平成 17 年 3 月に地元小学校 2 校（ともに当時小学校 5 年生）の総合的な学習の時間で実際に演示した。このとき の授業プログラムの流れは下記の通りである(6)(8),(9)。

グループ1「身の回りのものを使って虹色を見てみよ う」

実験 $1 ：$ 光の進み方を見てみよう

実験 2 : 色のついていない光をゼラチンプリズムに当

\section{てると?}

実験 3 : 三色の光を合わせてみよう

実験 4 : CD-R と DVD-R に光を当ててみよう

グループ 2 「LED で遊ぼう」

実験 1 : LED を光らせよう

実験 2 : LED を使って電光掲示板を作ろう

グループ 1 のプログラムでは, 反射や屈折などの光の基 本的性質を復習した後，プリズムによる分光実験を行った。 次に, 白色光の分光の対照として光の三原色の原理に基づ く色の合成を実験し, 最後に CD-R や DVD-R などの光ディ スクでも分光が生じることを体験した。一方，グループ 2 のプログラムでは, LED と豆電球との比較などを通じて, その特徴や用途などを学習した。

実験当日は，学年 2 クラスが両テーマを交代で行った。 図 3 には, 当日の学生による説明風景の写真を示す。

当日は, 両学生グループとも, 小学生の各班に学生一人 ずつを TA 役として配置し, 実験の具体的な手順の説明・指 導を行った。また, このうち学生一人は, 図 3 に示したよ うなクラス全体への説明役も兼務した。

実際の実験授業では, 両テーマともに小学生の興味・関 心を引き付ける目的で, できるだけ手作業を行わせる体験 型の展開とする工夫をしていた。また, 実験に使用する材

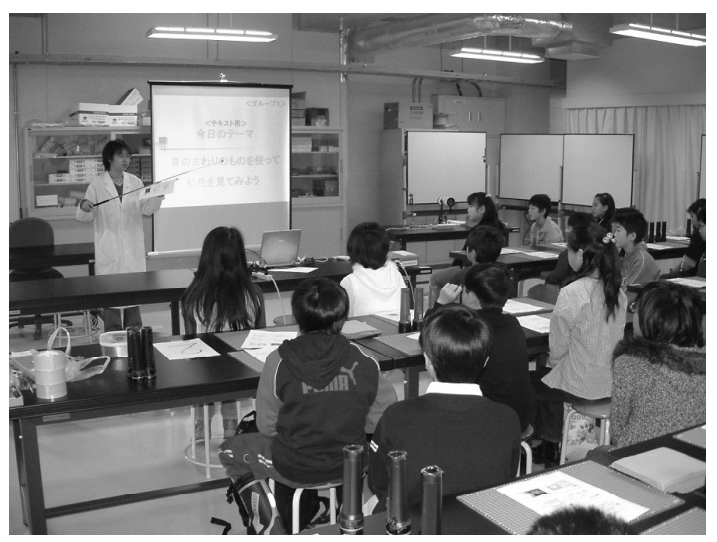

図 3 学生による実験授業の風景

Fig. 3. Experiment class by university students.

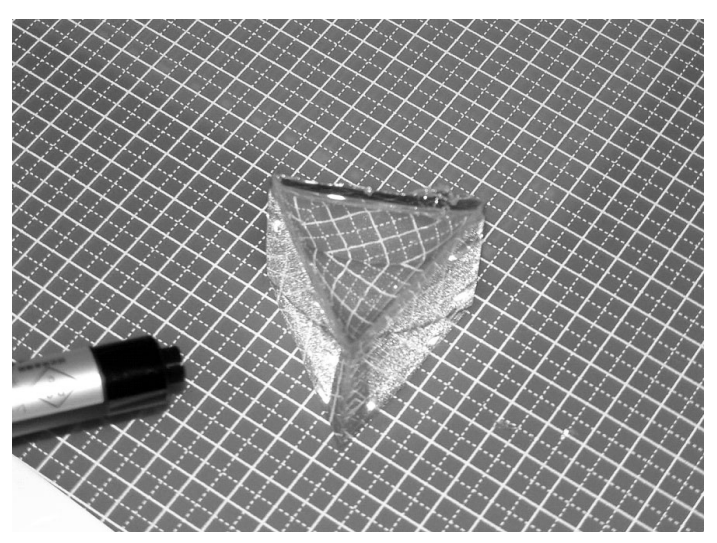

図 4 ゼラチンプリズム

Fig. 4. A prism made of gelatin. 
料・素材はできるだけ身近なものとして，興味があれば家 庭や学校で追実験が容易に行えるようにした。

例えば，グループ 1 では, 分光によるスペクトル観察に, 図 4 に示すようなゼラチンを使った「手作りプリズム」を 使用した。具体的には，事前に料理用タッパーの中に三角 柱状のプラスチック製の「型」を埋め込んだゼラチンを準 備しておき, 実験当日は, 小学生一人一人にゼラチンの中 から型を取り出させ，さらにそこから三角柱状になったゼ ラチン（すなわちゼラチンプリズム）を取り出させた。

学生による他の工夫点として, 小学生が積極的に現象を 観察し，それに基づいて自分の意見を発表する機会を設け るような配慮がなされた。そのために, 書込み式ワークシ 一トを作成して考察を促すなど，随所に学生の創意工夫が 認められた。

以上のような授業を前述のように小学 5 年生に対して演 示したが, 参加した小学生ならびに小学校教諭には,「興味 深い実験ができた」「楽しかった」「スライドや配布資料が 分かりやすく講師役の学生の説明も理解しやすかった」な ど, 総じて好評であった。

一方, 参加学生からは, 実験授業の実施後に次のような 感想が得られた。

・ テーマ検討から製作・実施に至るプロセスの中で, 様々なスキルアップの機会を得ることが出来た。

・「対話力」が向上した。

・仕事の進め方（報告・連絡・相談）で学ぶべき点が あり，また様々な工夫を行って効率化を図れた。

・「気付いた」点が多かった。

これらの学生の声から判断して, 課題の設定（教材テー マ選定）から解決（教材完成及び演示）に至る過程で様々 な能力・スキルの向上の機会を学生に提供するという効果 が，上手く実現できていると考えている。特に，自ら問題 点を見出し，自ら考え行動してその解決策を実現するとい う行動様式が, 参加した学生に根付いてきた。

上記のようなことを総合的に判断して，プロジェクトを 順調に立ち上げることができたと考えている。

〈3·3〉 プロジェクトの展開上記のような平成 16 年 度の活動を受けて, 平成 17 年度は, 6 月〜 7 月及び 11 月に それぞれ 1 回ずつの計 2 回，昨年度に実験授業を受けた同 じ小学校の同じ学年（現・小学 6 年生）を対象として実験 授業を行う。また, 平成 18 年 3 月には, 同じ小学校の現・ 小学 5 年生を対象とした実験授業を実施する。

なお，新年度になって新たな参加学生メンバを迎えたこ ともあって,グループは再編された。

昨年度中に実施した実験授業での実験テーマは学生グル ープが独自に選定したが, 今回は, プロジェクト参加学生 の発案により，新学期開始の時点で，今年度の実験授業を 受けることになる小学校 5,6 年生 174 名に「不思議に思っ ていること」及び「実験したいこと」を自由回答方式のア ンケートとして質問した。その結果に基づいて, 本年 $6 \sim 7$ 月の実験内容として「空の青さと夕焼け」及び「電気の世
界」をテーマとして選択した。これらについて, 昨年度の 活動と同様に学生グループが, 実験教材やそれに基づいた 授業プログラムを小学校教諭のアドバイスを得ながら考案 し，以下のような内容とした。

$$
\text { グループ } 1 \text { 「空の青さと夕焼け」(10) }
$$

実験 1 : 色のついた光（LED 光）が散乱される様子を 観察しよう

手作りの実験用水槽にアクリルエマルジョン溶液 を入れ, 一端から LED 光を照射して, 溶液内の光 の到達距離が各色で異なることを観察する。

実験 2 : 色のついていない光（懐中電灯の光）が散乱 される様子を観察しよう

上記水槽の一端から懐中電灯の光を照射し, 溶液 内の光の見え方を観察する。

実験 3 : 身の回りのものを使って夕焼けを作ろう

上記水槽にワックス, 牛乳, スポーツドリンクな どの溶液を入れて, きれいな夕焼け色の再現に挑 戦する。

グループ 2 「電気の世界」(9)

実験 1 : 電気を作ろう

工作用ギアボックスを用いた自作の手回し発電セ ットを使って LED，豆電球を点灯させる。

実験 $2:$ 水力発電を体験しよう

ギアボックスに手作り水車を取り付けた自作水力

発電セットで発電電圧值を測定する。

表 4 には, 上記 2 つの実験授業を平成 17 年 7 月に受けた 小学 6 年生 42 名に対するアンケート結果の一部を示す。 「空の青さと夕焼け」「電気の世界」と題する実験内容を理 解できたかどうかを 5 段階（最高＝5）で評価してもらった ところ, テーマによるばらつきはあるが, 比較的高い割合 で理解できた旨の回答が得られた。

$\langle 3 \cdot 4\rangle$ 地域教育への貢献効果の検討 今回のプロジ エクトは, 地域教育への貢献, 及び参加学生の教育・スキ ル向上という 2 つの教育効果をねらっている。

このうち地域教育の側面に関して, 先述のように, 学生 による実験授業を受けた小学生からは, 総じて楽しかった という感想が得られた。また, 小学校教諭からは, 小学校 での普段の授業と比較して, 内容や環境が異なるので単純 な比較はできないものの平均的に興味・集中度は高かった

\section{表 4 「実験内容は理解できたか」に対する回答}

Table 4. Responses to the questionnaire.

"Were the contents of experiments understandable?"

\begin{tabular}{|c|c|c|}
\hline & Blue sky and sunset & Electricity \\
\hline 5 & $74 \%$ & $55 \%$ \\
\hline 4 & $24 \%$ & $26 \%$ \\
\hline 3 & $0 \%$ & $14 \%$ \\
\hline 2 & $2 \%$ & $5 \%$ \\
\hline 1 & $0 \%$ & $0 \%$ \\
\hline
\end{tabular}


という意見も得られた。但し，今回の実験授業の受講が理 科の授業内容への関心の向上をもたらしたかに関しては, 短期間では判断できず, 長期的な検討・評価が必要になっ ている。

この点に関して，平成 17 年度からは小 5 〜小 6 にかけて 計 3 回の理科実験授業を継続的且つ連携した内容で実施す る計画であり，これによって，より効果的な啓蒙効果や理 科離れ抑制効果が得られるかどうか, 検討を進める。

$\langle 3 \cdot 5\rangle$ 参加学生への教育効果の検討 参加学生の教 育という側面に関して，これまでの実験授業プログラムの 作成作業を通じた各学生グループの活動状況や個々の学生 メンバの行動などの観察結果から判断すると, 学生メンバ には, 企画力・計画力・改善力・実行力・対話力など様々 な能力・スキルの向上効果が認められる。また, 前述した ように，新しい実験テーマ策定の資料とするための小学生 対象のアンケート実施は学生の発案であり, 自主的・主体 的な行動力の向上も認められる。

さらに学生の物理教育に関して, 実験内容に関連する物 理現象を小学生に分かりやすく教えるためには, 学生自身 がその現象を十分に理解している必要があり, 結果的に学 生自身の知識の再確認・再構築の場ともなっている。

このような教育効果の客観的・定量的な判断の第一歩と して，参加学生に対するアンケートを実施した。具体的に は，各種の能力をリストアップした上で，これまでの活動 を通じて「獲得したと思う能力」「足りないと感じた能力」 を, 複数回答を可として選択してもらった。なお，回答し た学生は計 17 名で, アンケート実施時点でそれぞれ少なく とも 2 テーマの授業プログラム開発作業に従事した経験を 有している。結果を図 5(a)及び図 5(b)に示す。

図 5(a)に示す「獲得したと思う能力」では，「コミュニケ ーション能力」「協調性」「行動力」が多く選択された。こ れらは，グループとしての共同作業を通じて培われたもの と考えられる。これらに続いて「新たな専門知識」（設問上 は「既習知識の再認識」も含む）が多く選択されたが，や はり実験内容の検討作業を通じて必然的に習得・再確認を 迫られたものと思われる。

一方, 図 5(b)には「足りないと感じた能力」に関する回 答結果を示す。特徵的なことは, 図 $5(\mathrm{a})$ に示した「獲得し たと思う能力」より，選択された数が全体的に多くなって いる点である。これは, 先に〈3.2〉の中で述べた学生の感 想の中で，「気付いた点が多かった」という意見に通じるも のと考えられる。

具体的には，「コミュニケーション能力」「協調性」など 図 5(a)で獲得できたと選択された能力が(b)では相対的に低 くなったが,「プレゼンテーション能力」「スケジューリン グ・時間管理能力」などの不足を実感した学生が多くなっ た。本プロジェクトは, 基本的には参加学生の主体的な活 動に任せることを大きな方針としている。その意味では, 身に付けるべき又は向上させるべき能力・スキルを学生に 認識させる機会を提供し, 且つ実際に学生自らがそれらを

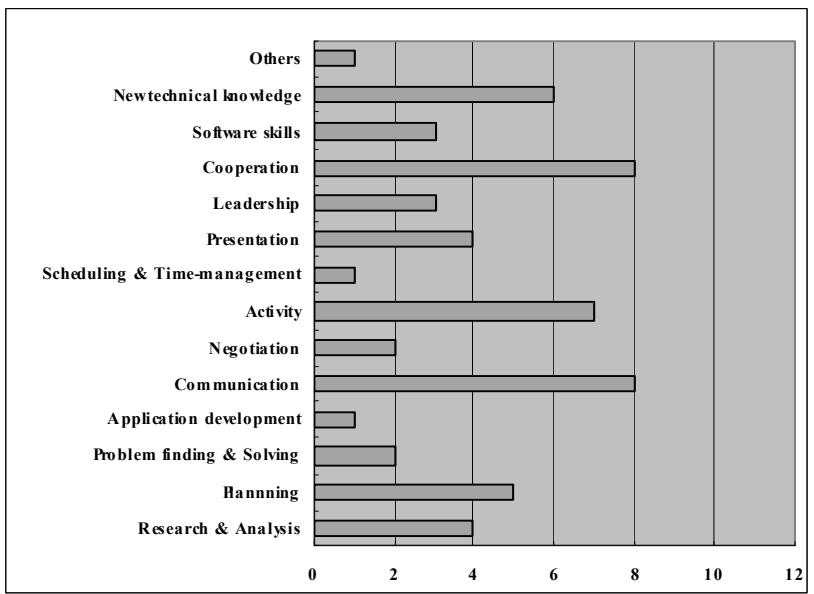

(a) What you felt you obtained

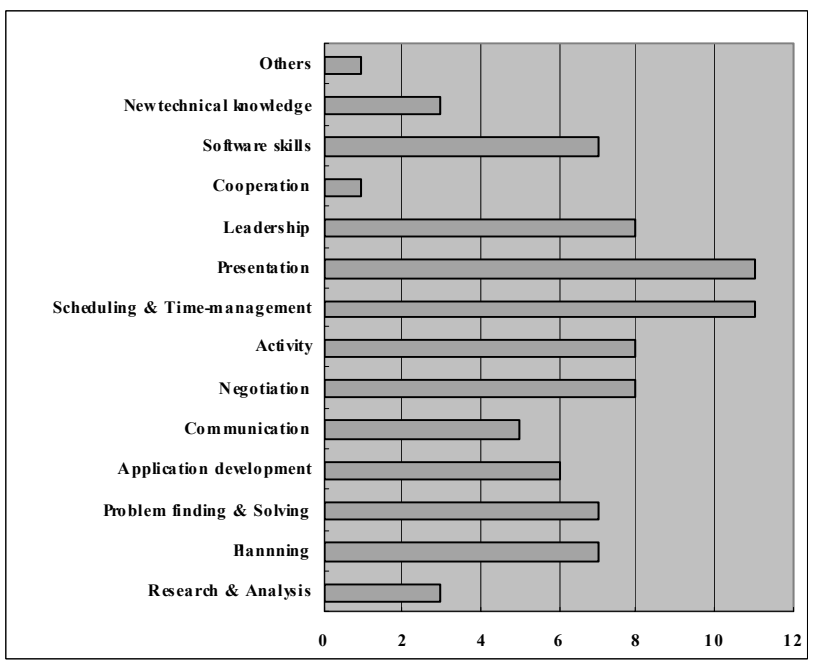

(b) What you felt you lacking

図 5 プロジェクト参加学生へのアンケート結果

（複数回答選択可能方式）

Fig. 5. Responses to the questionnaire of project members (by selecting multiple answers).

認識できたという点で, 通常の受動的な講義や学生実験で は得難い効果を達成できていると言うことができる。

その一方で, プレゼンテーション能力や各種ソフトウエ アのスキルなど, 学生が「足りない」「向上の必要がある」 と認識した能力・スキルを向上させる方策も必要になる。 ここで再び図 $5(\mathrm{a})$ をると, これらの能力を「獲得した」 と回答した学生も存在することが分かる。これは, グルー プ内で役割分担ができた結果, 個々の学生が習得できた能 力・スキルに差が生じた可能性がある。この点に関しては 初回の授業終了時に既に参加学生からも危惧する声が上が っており, 学生グループ編成を新規授業の開発毎に改変す ることで, 学生間の役割の固定化を防ぎ, 様々な能力・ス キルの獲得・向上の機会を広く提供することを図ってきた。 しかし, 図 5(b)に示される結果は, まだ改善の余地が存在 していることを示している。現時点では, 学生グループの 編成方針や改変タイミングの最適化を図りながら, 能力・ スキルの獲得・向上効果への影響を検討していくことが考 
えられ, 今後の課題である。

また，この点に関連して，例えば「プレゼンテーション 能力」について言えば，実験授業におけるクラス全体への 説明役が結果的に各グループリーダに限定されたことも， 獲得の程度に関係していると考えられる。これについては, 「指導力 (リーダシップ)」や「折衝力」など他の能力・ス キルも含めて，本プロジェクトを継続して多くの学生（特 に現時点での下級生の学生）が次第にグループリーダを担 当することで，解消されていく可能性がある。

なお，以前に述べたように本プロジェクトには，単科大 学である本学の 1 学部 2 学科から学年・所属学科に無関係 に学生が参加している。本プロジェクトにおける活動を通 じた学生の能力・スキルの獲得・向上と学年・所属学科と の関連に付いて言えば, 上述のように学年との若干の相関 は認められるが, 所属学科との関連は認められない。むし ろ, 異なる学年・学科の学生が協働作業を行うことによる 相乗効果の方が大きいと考えられる。

〈3.6〉 今後の展開 本稿 2 章で述べたリレーティー チング・プロジェクトに比べて本プロジェクトでは，単な る実験授業の実施に限らず，そのための準備段階から学生 が主体的に行動することから，より広範囲な能力・スキル の獲得・向上が期待できる。その一方で, TA としての小学 生への実験内容の説明に関しては, リレーティーチング方 式では高校生を介した二段階となるので，本プロジェクト における TA とは性格が異なっている。今後は, 両者を結合 し，本プロジェクトで学生が計画・準備した実験授業の実 施にリレーティーチング方式を取り込むことも，検討を進 めていきたい。

一方，平成 17 年度下期からは，これまでに作成した実験 授業内容の電子教材化作業に着手した。具体的には，実験 風景と関連知識・ワークシート類が一体化したコンテンツ の作成を目指して，現在，製作指針の確定や含めるべき内 容・項目などの検討作業を進めている。この電子教材作成 作業を通じて, 参加学生には, 企画力・行動力・検討力な ど将来の研究開発活動にもつながる能力を養う機会が提供 され，且つプログラミングスキルなどの実務能力を向上さ せる機会にもなる。さらに, 上記の電子教材を小学校の授 業内で使い易い（使う気になる）ものとするには小学校教 諭からの意見が久かせないが，そのための連携した検討作 業を通じた折衝力の向上も見込まれる。こうした活動にで きるだけ多くの学生を関与させることで, 広範囲な能力・ スキルの獲得・向上の機会を提供していく予定である。

また, 各種の能力・スキルの向上効果の判定に関して, 現段階では, 〈3・5〉節で述べたような参加学生の自覚に依 存した評価を実施したのみである。これに対して，何らか の客観的な評価基準を定めて, それに基づいて個々の学生 の能力・スキルの向上の度合いを客観的に判定することが できれば，本プロジェクトの学生教育への効果をより詳細 に検討することが可能になる。このような客観的な評価基 準に基づく評価・判断などの実施は，今後の課題である。

\section{4. むすび}

地域の初等中等教育への貢献・活性化を目的として実施 する理科実験教室などを大学生（及び高校生）の教育機会 として積極的に活用することを目指した新しい教育プログ ラムの試みについて，その概要を報告した。

「リレーティーチング」による指導形態を取り入れた理 科実験教室では, 大学生（及び高校生）に対して他人に教 える機会を積極的に与えることで, 自らの知識の再認識・ 再構築のきっかけ，さらにはプレゼンテーションに関連す る様々なスキルを身に付けるきっかけとすることができ た。

学生による理科実験授業開発プロジェクトでは，企画・ 行動・達成力などのさまざまな能力を学生に付けさせる機 会になるとともに, 学生の自主性や主体性の育成・向上な どの点での教育効果が認められつつある。

より大きな効果を得るために改善すべき点が数多く存在 していることは事実であるが，小学校から大学までの教育 機関がより密接に連携していくことで, 従来とは異なる理 科・科学教育の新しい形態を実現する可能性が示せたもの と考えている。

\section{謝 辞}

本論文で述べた教育プログラムの実施にあたり，平成 16 年度文部科学省・大学等開放推進事業「大学 Jr. サイエンス 事業」, ならびに平成 16 年度文部科学省「現代的教育ニー ズ取組支援プログラム」による支援に感謝致します。また, 理科実験授業の実施にあたり，千歳市，千歳市教育委員会， 千歳市立千歳小学校・緑小学校, 北海道立千歳高等学校・ 千歳北陽高等学校・恵庭北高等学校 $\cdot$ 恵庭南高等学校の関 係各位からのご協力に深謝致します。

(平成 17 年 8 月 22 日受付, 平成 18 年 1 月 10 日再受付)

\section{文献}

(1) J. Imai, A. Yamanaka, and H. Komatsugawa : "Remedial education for science and technology through e-Learning", Jpn. J. Appl. Phys. Education, Vol.29, No.1, pp.35-40 (2005-7) (in Japanese)

今井順一・山中明生・小松川浩 : 「e-Learning による理数系基礎教 育の実施例」, 応用物理教育, 29, No.1, pp.35-40 (2005-7)

(2) N. Kuzuu : "Importance of writing in a course for applied physics students”, Jpn. J. Appl. Phys. Education, Vol.29, No.1, pp.9-15 (2005-7) (in Japanese)

葛生 伸:「応用物理系学科専門教育科目における「書かせる教育」」, 応用物理教育, 29, No1, pp.9-15 (2005-7)

(3) M. Funato, M. Yoshimoto, and K. Tachibana : "Report on "Refresh" science school held by Kansai branch", Jpn. J. Appl. Phys. Education, Vol.28, No.2, pp.27-32 (2004-12) (in Japanese) 船戸 充・吉本昌広・橘 邦英:「リフレッシュ理科教室 (関西支部) 開催報告」, 応用物理教育, 28, No.2, pp.27-32 (2004-12)

(4) N. Takahashi, K. Tsutsui, A. Hirose, Y. Saito, and M. Tanemura : "Visit to the basics of science -efforts at science education and publicity-", Proc. $22^{\text {nd }}$ Physics Education Research Convention, pp.60-61 (2005-8) (in Japanese)

高橋憲明・筒井和幸・廣瀬明浩・斎藤吉彦・種村雅子 :「科学の基礎 を訪ねる一新しい理科教育・啓蒙の試み一」, 日本物理教育学会第 22 回物理教育研究大会発表予稿集, pp.60-61 (2005-8) 
(5) M. Hasegawa and K. Ishida : "A trial of relay-teaching from university students to high school students and further to elementary school students", Buturi Kyoiku Kenkyu, Vol.33, pp.57-62 (2005-7) (in Japanese)

長谷川誠・石田宏司 :「大学生・高校生・小学生間のリレーティーチ ングの試み」, 物理教育研究（日本物理教育学会北海道支部会報）, 33 , pp.57-62 (2005-7)

(6) M. Hasegawa and K. Ishida : "Development of science experiment programs and their web-based contents by university students", Buturi Kyoiku Kenkyu, Vol.33, pp.63-67 (2005-7) (in Japanese)

長谷川誠・石田宏司：「学生による理科実験授業プログラム及びその 電子化コンテンツの開発の試み」, 物理教育研究 (日本物理教育学会 北海道支部会報)，33，pp.63-67 (2005-7)

( 7 ) K. Morita, T. Matsui, M. Hasegawa, and K. Ishida : "A simplified experiment demonstration set of optical communication with LEDs", Proc. 22 $2^{\text {nd }}$ Physics Education Research Convention, pp.126-127 (2005-8) (in Japanese)

森田恭平・松井丈夫・長谷川誠・石田宏司：「LED を用いた簡易光 通信模擬実験セット」, 日本物理教育学会第 22 回物理教育研究大会 発表予稿集, pp.126-127 (2005-8)

(8) M. Hasegawa, T. Matsui, K. Morita, and K. Ishida : "An experiments of spectrum observation with a transparent-type grating film and simplified calculation of wavelengths of light", Proc. 22 $2^{\text {nd }}$ Physics Education Research Convention, pp.130-131 (2005-8) (in Japanese)

長谷川誠・松井丈夫・森田恭平・石田宏司：「透過型回折格子フィル ムを用いた分光と光の波長の簡易計算実験」, 日本物理教育学会第 22 回物理教育研究大会発表予稿集, pp.130-131 (2005-8)

(9) T. Matsui, T. Abe, H. Yoshida, Y. Makino, M. Hasegawa, and K. Ishida : "Development and demonstration of science experiment programs for elementary school students entitled "Let's play with LEDs" and "The world of electricity"', Proc. 22 $2^{\text {nd }}$ Physics Education Research Convention, pp.128-129 (2005-8) (in Japanese)

松井丈夫・阿部太郎・吉田博一・牧野瑶子・長谷川誠・石田宏司:「小 学生向け「LED で遊ぼう」「電気の世界」理科実験授業プログラム の開発とその演示」, 日本物理教育学会第 22 回物理教育研究大会発 表予稿集, pp.128-129 (2005-8)

(10) N. Kato, K. Shintani, S. Yoshida, Y. Yamaguchi, K. Honda, K. Yamada, M. Hasegawa, and K. Ishida : "Development and demonstration of science experiment programs for elementary school students entitled "Colors of blue sky and sunset"', Proc. 22 $2^{\text {nd }}$ Physics Education Research Convention, pp.132-133 (2005-8) (in Japanese)

加藤尚斗・新谷和也 - 吉田周平 - 山口洋平 - 本田行佑 - 山田健一 . 長谷川誠・石田宏司:「小学生向け「空の青さと夕焼け」理科実験授 業プログラムの開発とその演示」, 日本物理教育学会第 22 回物理教 育研究大会発表予稿集, pp.132-133 (2005-8)

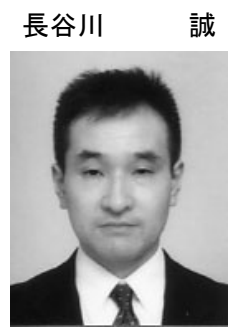

に従事。

石田宏司

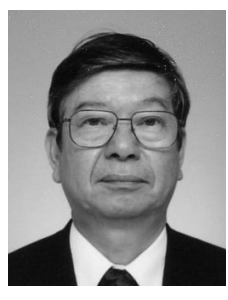

事。
(正員) 1963 年 8 月 14 日生まれ。 1986 年 3 月慶應義塾大学理工学部電気工学科卒業。1991 年 3 月同大大学院理工学研究科電気工学専攻博 士課程修了。現在, 千歳科学技術大学光科学部 光応用システム学科助教授。電気接点現象, 機 構デバイスの信頼性, 光応用計測に関する研 究, ならびに理科実験教材・授業プログラムの 開発とそれによる教育効果検討プロジェクト

(非会員) 1941 年 9 月 4 日生まれ。1965 年 3 月北海道大学理学部物理学科卒業。1972 年 3 月同大大学院理学研究科物理学専攻博士課程 修了。現在, 千歳科学技術大学光科学部物質光 科学科教授ならびに同学科主任。光インターコ ネクション, フォトニック結晶に関する研究, ならびに理科実験教材・授業プログラムの開発 とそれによる教育効果検討プロジェクトに従 